\title{
Occupational Exposure Assessment of Major and Trace Elements in Human Scalp Hair Among a Group of Eritrean Workers
}

\author{
Carmela Protano ${ }^{1}$ - Maria Luisa Astolfi ${ }^{2}$ - Elisabetta Marconi ${ }^{1}$ - Arianna Antonucci ${ }^{1}$ - Silvia Canepari ${ }^{2}$. \\ Daniel Piamonti ${ }^{3} \cdot$ Marco Brunori $^{3}$ - Matteo Vitali ${ }^{1}$
}

Received: 31 July 2019 / Accepted: 15 November 2019 / Published online: 2 December 2019

(C) Springer Science+Business Media, LLC, part of Springer Nature 2019

\begin{abstract}
The aim of the study was to evaluate occupational exposure to 40 elements among a group of Eritrean adults employed at the Medeber metal market by analysing human scalp hair samples and by investigating the role of some predictors (gender, age, and body mass index-BMI) on their levels. Scalp hair samples were collected from 60 subjects (32 subjects working at the Medeber metal market and 28 subjects not working at Medeber and not employed in other industrial or artisanal activities) and were analysed through inductively coupled plasma mass spectrometry to determine the contents of 40 major and trace elements. Information on participants was collected via questionnaire. Significant differences were found in the hair levels of certain elements between subjects working at the Medeber metal market and subjects not exposed. In particular, working at the Medeber metal market increased hair levels of $\mathrm{Be}, \mathrm{B}, \mathrm{Cu}, \mathrm{Zn}, \mathrm{Mo}, \mathrm{Cd}, \mathrm{Sb}, \mathrm{Tl}, \mathrm{Pb}$, and Fe from 25 to $100 \%$, while reduced $\mathrm{Na}, \mathrm{K}$, and $\mathrm{Rb}$ levels from 30 to $50 \%$. With multivariate adjustment for age, gender, and BMI, the results confirm that working at Medeber significantly increased the hair levels of $\mathrm{Cu}, \mathrm{Zn}, \mathrm{Sb}, \mathrm{Pb}$, and $\mathrm{Fe}$. This finding reveals the need for more accurate and routine biomonitoring surveys and the necessity of health promotion campaigns both for local decision-makers and workers to increase health promotion and safety in this workplace.
\end{abstract}

Keywords Trace elements $\cdot$ Heavy metals $\cdot$ Scalp hair $\cdot$ Occupational exposure $\cdot$ Human biomonitoring $\cdot$ Eritrea

\section{Introduction}

The evaluation of a population's exposure to toxic compounds in occupational setting by biomonitoring is a tool whose relevance for public health has become increasingly apparent [1-6].

Typical biological matrices used for human biomonitoring are blood and urine, both for assessing occupational scenarios

\footnotetext{
Matteo Vitali

matteo.vitali@uniroma1.it

Carmela Protano

carmela.protano@uniroma1.it

Maria Luisa Astolfi

marialuisa.astolfi@uniroma1.it

Elisabetta Marconi

elisabetta.marconi@uniroma1.it

Arianna Antonucci

arianna.antonucci@uniroma1.it

Silvia Canepari

silvia.canepari@uniroma1.it
}

$[7,8]$ and the general population [9-11]. In the last few decades, scalp hair has become an interesting bioindicator in various disciplines, such as the biological, medical, environmental, and forensic fields [12-14]. Human hair, with respect to other biological matrices such as blood, nail, urine, and saliva, has greater stability and is easier to collect, store, and transport [15]. In addition, the levels of compounds found in human hair reflect a medium-long exposure time since hair

Daniel Piamonti

daniel.piamonti@gmail.com

Marco Brunori

marco.brunori@uniroma1.it

1 Department of Public Health and Infectious Disease, Sapienza University, Piazzale Aldo Moro 5, I-00185 Rome, Italy

2 Department of Chemistry, Sapienza University, Piazzale Aldo Moro 5, I-00185 Rome, Italy

3 Department of Cardiovascular, Respiratory, Nephrology, Anaesthesiology and Geriatric Science, Sapienza University, Piazzale Aldo Moro 5, I-00185 Rome, Italy 
grows approximately $1 \mathrm{~cm}$ per month. Consequently, the concentration of an analyte in this matrix represents its level in the body medium from which it was formed, and provides information on "historical" intake from air, water, food, and dermal contact [16] of a great number of environmental contaminants, including organic compounds [17-20] and inorganic elements [21-24].

In regard to major and trace elements, human scalp hair is considered a good screening tool for assessing the concentration of essential elements and heavy metals because it incorporates elements into its structure during the growth process [25]. In the course of the years, some studies were performed to evaluate the possibility to use hair samples instead of urine or blood to biomonitor the workers' exposure. For instance, Reiss et al. reported that hair was a better biomarker for inhaled manganese $(\mathrm{Mn})$ exposure with respect to urine and blood because hair is less influenced by short-term variability of Mn exposure concentrations due to its slow growth rate [26]. Skalny et al. assessed the levels of aluminium and other toxic metals in hair of workers employed in the hydrometallurgical and sintering units of an aluminium plant. They demonstrated significantly higher levels of the monitored toxic metals in aluminium plant workers with respect to the control group. Besides, the authors evidenced that working in different technological processes was associated with a specific metal profile in hair samples [27]. Similar results in term of specific profiles in hair levels of toxic and essential trace elements related to different working processes were recovered by the same authors in workers involved in different departments of a petrochemical plant [28]. Also, Nouioui et al. [29] evaluated the hair levels of essential and toxic elements of a sample of workers in a $\mathrm{Pb}$ battery manufacturing plant and the influence of some confounding factors (age, work activity, and lifestyle habits) on hair elements' levels. They demonstrated that age, the type of work activity, and smoking significantly impact on the level of some elements in hair samples. Traditionally, the results of occupational biomonitoring do not take into account the influence of gender, age, and other possible interfering/confounding factors. In contrast, several studies demonstrated the significant role of some factors on the levels of elements and compounds in biological matrices. For instance, Sukumar [30] focused attention on four main categories of predictors accounting for the variability in the levels of compounds in biological matrices: biological, personal, environmental, and analytical/methodological factors. Other studies reported relevant differences related to gender, age, race/ethnicity, and geographical area of residence [23]. Regarding this last variable, populations living in developing countries are not studied in as great depth as those living in developed countries. Thus, an essential research agenda is to carry out studies in the field specifically performed in such areas and researches assessing the role of some variables on the results of the biomonitoring performed to assess occupational exposure.

In addition, further efforts should be devoted to develop, optimize, and apply in-field analytical methods suitable to determine and quantify, with a unique analysis, a great number of analytes at trace/ultratrace concentrations. In this way, the method becomes cost-effective and consumes little time and thus is reliable for investigating large populations as is necessary for biomonitoring studies [31, 32].

The aims of the present study were (1) to evaluate the occupational exposure to 40 elements among a group of Eritrean adults employed at the Medeber metal market by analysing human scalp hair samples and (2) to investigate the role of some confounding/interfering variables (gender, age, and body mass index-BMI) on the levels of the monitored elements.

\section{Materials and Methods}

\section{Study Area and Design}

The research, consisting of a cross-sectional study, was conducted on a sample of Eritrean adults selected in Asmara, the capital of the small East African country of Eritrea. In particular, we recruited 60 volunteers, of whom 32 subjects were employed at the Medeber market, and 28 of whom had similar demographic characteristics and were employed in administrative work at other companies located far from the Medeber market. These subjects were randomly selected from a larger population of 840 subjects participating in the "Medeber project", a research project carried out in collaboration with the Italian nonprofit organization "ASS.ITER. Onlus" that includes both intervention and epidemiological studies focused on Eritrean adults.

The Medeber market, also called the Metal Market, is an ironwork site in Asmara. In Medeber, almost all types of metals are used for making stoves, coffee pots, desks, doors, axes, chairs and so on. In addition, in the Medeber market, "berberé", a mixture of spices that acts as a key ingredient in Eritrean cuisine, is processed [33].

This study was approved by the Minister of Health of Eritrea through acknowledgement of the ASS.ITER. Onlus, within the "Medeber project" and it was conducted in accordance with the Declaration of Helsinki. Before collecting scalp hair samples and some individuals' information, each recruited individual was fully informed about the aim of the study, the method used for the analysis of the collected samples, and how her/his identity and privacy would have been protected. To guarantee the complete understanding of all the given explanation on research project, a cultural linguistic mediator was always present during all the phases of the 
project involving Eritrean individuals. The subjects who decided to participate filled out the questionnaire and donated the hair sample. In addition, in order to guarantee the anonymity of each participant, no personally identifying information was collected.

During the monitoring campaign performed in Asmara (Eritrea) in 2017 as a part of the Medeber project, a total of 60 scalp hair samples were obtained from an equal number of volunteers, among which 32 subjects worked at the Medeber market and 28 subjects with similar demographic characteristics did not work at Medeber nor were employed in industrial or artisanal activities. For each subject, a sample of approximately $2 \mathrm{~g}$ of previously washed hair was obtained by cutting with stainless-steel scissors as close as possible to the scalp according to the method used in previous studies [34, 35]. Each hair sample was inserted in a polyethylene zip-lock bag and stored in the dark until the analysis.

\section{Data Collection}

Information about the studied subjects was gathered by an "ad hoc" questionnaire created for the present study and translated into Tigrinya (the language spoken by the studied population) and validated before the start of the study. The questions investigated the demographic characteristics of the participants, their anthropometric data (height and weight), and smoking habits. Data collected by the questionnaire were then coded and entered into a specifically designed database.

With respect to the occupational scenario, participants were grouped according to their working site as "not working at Medeber" (categorized as 0) and "work at Medeber" (categorized as 1). Other data used for statistical elaboration were codified as follows:

- Gender was classified as $0=$ male and $1=$ female;

- Age was calculated on the basis of birth date and used as a continuous variable (years);

- Smokers were categorized as $0=$ no smoker and $1=$ smoker;

- Ponderal status for each participant was assessed by the use of BMI, calculated by dividing the weight (in kilogrammes) by the height (in metres squared). BMI was then used as a continuous variable.

\section{Equipment}

Analytical determinations of all elements (Al, aluminium; As, arsenic; $\mathrm{B}$, boron; $\mathrm{Ba}$, barium; $\mathrm{Be}$, beryllium; $\mathrm{Bi}$, bismuth; $\mathrm{Ca}$, calcium; $\mathrm{Cd}$, cadmium; $\mathrm{Ce}$, cerium; $\mathrm{Co}$, cobalt; $\mathrm{Cr}$, chromium; $\mathrm{Cs}$, caesium; $\mathrm{Cu}$, copper; $\mathrm{Fe}$, iron; $\mathrm{Ga}$, gallium; $\mathrm{K}$, potassium; $\mathrm{La}$, lanthanum; $\mathrm{Li}$, lithium; $\mathrm{Mg}$, magnesium; $\mathrm{Mn}$, manganese; Mo, molybdenum; $\mathrm{Na}$, sodium; $\mathrm{Nb}$, niobium; $\mathrm{Ni}$, nickel; $\mathrm{P}$, phosphorus; $\mathrm{Pb}$, lead; $\mathrm{Rb}$, rubidium; $\mathrm{Sb}$, antimony; Se, selenium; $\mathrm{Si}$, silicon; $\mathrm{Sn}$, tin; $\mathrm{Sr}$, strontium; Te, tellurium; Ti, titanium; $\mathrm{Tl}$, thallium; $\mathrm{U}$, uranium; $\mathrm{V}$, vanadium; $\mathrm{W}$, tungsten; $\mathrm{Zn}$, zinc; and $\mathrm{Zr}$, zirconium) were performed by inductively coupled plasma mass spectrometry (ICP-MS; 820-MS; Bruker, Bremen, Germany) equipped with a collisionreaction interface (CRI) and glass nebulizer $\left(0.4 \mathrm{~mL} \mathrm{~min}^{-1}\right.$; MicroMistTM; Analytik Jena AG, Jena, Germany). Al, B, Ba, $\mathrm{Be}, \mathrm{Bi}, \mathrm{Ca}, \mathrm{Cd}, \mathrm{Co}, \mathrm{Cs}, \mathrm{Cu}, \mathrm{K}, \mathrm{Li}, \mathrm{Mg}, \mathrm{Mo}, \mathrm{Na}, \mathrm{Ni}, \mathrm{P}, \mathrm{Pb}, \mathrm{Rb}$, $\mathrm{Sb}, \mathrm{Si}, \mathrm{Sn}, \mathrm{Sr}, \mathrm{Te}, \mathrm{Ti}, \mathrm{Tl}, \mathrm{U}$, and $\mathrm{Zn}$ were quantified in the standard mode, while As, $\mathrm{Cr}, \mathrm{Fe}, \mathrm{Mn}, \mathrm{Se}$, and $\mathrm{V}$ were determined by CRI, with $\mathrm{He}$ and $\mathrm{H}$ (99.9995\% purity; SOL Spa, Monza, Italy) as cell gases.

A microanalytical balance (Gibertini E505; Gibertini Elettronica, Milan, Italy) was used to weigh the human hair samples. A water bath (WB12; Argo Lab, Modena, Italy) set at $95 \pm 0.2{ }^{\circ} \mathrm{C}$ was used for the open vessel digestion.

The detailed analytical procedure and the list of instrumental parameters were reported in previous papers $[32,36]$.

\section{Chemicals and Other Materials}

The standard solutions for the seven-point external standard calibration of ICP-MS were matrix-matched and prepared from standard stock solutions (Ultra Scientific Analytical Solutions, N. Kingstown, RI, USA) at $1.000 \pm 0.005 \mathrm{mg} \mathrm{L}^{-1}$ for As, Al, Ba, Be, Bi, Cd, Cr, Cs, Cu, Li, Mn, Mo, Ni, Pb, Rb, $\mathrm{Sb}, \mathrm{Se}, \mathrm{Sn}, \mathrm{Te}, \mathrm{Ti}, \mathrm{Tl}, \mathrm{U}$, and V; at $5.00 \pm 0.03 \mathrm{mg} \mathrm{L}^{-1}$ for B, $\mathrm{Co}$, and $\mathrm{Sr}$; at $10.00 \pm 0.05 \mathrm{mg} \mathrm{L}^{-1}$ for Fe and $\mathrm{Zn}$; at $50.00 \pm$ $0.25 \mathrm{mg} \mathrm{L}^{-1}$ for B, P, Si, and $\mathrm{Sr}$; at $500.0 \pm 2.5 \mathrm{mg} \mathrm{L}^{-1}$ for K, $\mathrm{Mg}$, and $\mathrm{Na}$; and, finally, at $1000 \pm 5 \mathrm{mg} \mathrm{L}^{-1}$ for Ca. Yttrium was prepared from a standard stock solution (1000 \pm $2 \mathrm{mg} \mathrm{L}^{-1}$; Panreac Química, Barcelona, Spain) and used as internal standard for all the measurements, as previously reported [37-39].

Deionized water (resistivity $\leq 18.3 \mathrm{M} \Omega \mathrm{cm}^{-1}$ ) was produced by an Arioso Power I RO-UP Scholar UV deionizer (Human Corporation, Songpa-Ku, Seoul, Korea). High purity nitric acid (67\%) and hydrogen peroxide (30\%) were purchased from Promochem, LGC Standards GmbH (Wesel, Germany).

Syringe filters (cellulose nitrate membranes, $0.45 \mu \mathrm{m}$ pore size) were supplied by GVS Filter Technology (Indianapolis, USA) and graduated tubes (2.5-5-10 mL in polypropylene) were purchased from Artiglass s.r.l. (Due Carrare, PD, Italy).

\section{Sample Treatment and Analysis}

Weighed amounts (approximately $20 \mathrm{mg}$ ) of each hair sample washed according to a procedure described previously [34, 35 ] were transferred into a polypropylene tube, mixed with $0.5 \mathrm{~mL}$ of $67 \% \mathrm{HNO}_{3}$ and $0.25 \mathrm{~mL}$ of $30 \% \mathrm{H}_{2} \mathrm{O}_{2}$, and then heated in the water bath for $20 \mathrm{~min}$ at $95{ }^{\circ} \mathrm{C}$. The obtained 
solution, clear and without visible suspended and/or sedimented residues, was diluted to $10 \mathrm{~mL}$ with deionized water and then filtered through a syringe filter as a precaution. Each filter was pre-cleaned with $30 \mathrm{~mL}$ of $2 \% \mathrm{HNO}_{3}$.

Blank tests were performed with the same procedure, and results were subtracted from data obtained on hair samples.

\section{Analytical Validation}

Linearity, limits of detection (LODs), accuracy, and selectivity of the method were investigated to validate the applied procedure under the instrumental optimized conditions. Briefly, the calibration standards were analysed daily and in sequence; an $R^{2}$ value at least equal to 0.999 was accepted. The linearity range was verified by the Mandel fitting test. The LODs (Table 1) were set at three times the standard deviation (SD) of the blank samples (10 measurements), obtained using the same digestion procedure. Accuracy (as trueness bias\% or recovery \%) was evaluated using the certified material (European reference material (ERM) DB001; sample n. 0196; Joint Research Centre, Geel, Belgium). Recovery studies were carried out by adding a known amount of the elements to ERM DB001 (six replicates, $0.02 \mathrm{~g}$ ). The precision (as repeatability) of the measurements was $<12 \%$ for all the analysed elements, while the trueness bias for all the certified elements ( $\mathrm{As}, \mathrm{Cd}, \mathrm{Cu}, \mathrm{Pb}, \mathrm{Se}$, and $\mathrm{Zn}$ ) in the range from -4 to $9 \%$; finally, recoveries were in the range $90-110 \%$ for all the target elements except $\mathrm{Cr}(65 \%)$ and $\mathrm{Fe}(79 \%)$.

\section{Drinking Water Analysis}

Drinking water analyses were performed by following Italian Official methods [40]. Each water sample $(10 \mathrm{~mL})$ was added with $100 \mu \mathrm{L}$ of $67 \% \mathrm{HNO}_{3}$ in a polypropylene tube and sonicated in an ultrasonic bath (Ultrasonic UTA 15, Falc Instruments S.r.l., Lurano, BG, Italy) for $20 \mathrm{~min}$ to remove $\mathrm{CO}_{2}$. Potentially interfering polyatomic ions $\left({ }^{40} \mathrm{Ar}^{16} \mathrm{O}\right.$, ${ }^{40} \mathrm{Ar}{ }^{35} \mathrm{Cl},{ }^{40} \mathrm{Ar},{ }^{38} \mathrm{Ar}$ ) were removed by using a CRI as previously reported [32]. Accuracy (trueness bias\%) was evaluated using a water standard reference material (SRM 1643e trace elements in water; National Institute of Standards and Technology, NIST; Gaithersburg). Trueness bias percentages in the range -5 to $10 \%$ for all the studied elements were found, while the percent relative standard deviation for the repeatability did not exceed the $10 \%$-limit.

\section{Statistical Analysis}

Statistical analyses were carried out using IBM SPSS Statistics 25 software (IBM Corp., Armonk, NY, USA). For each element, when more than $20 \%$ of the samples resulted in $<$ the limit of determination (LOD), the element was excluded from the statistical calculation; in the other cases, if one or more values were below the LOD, they were replaced with a value equal to half the LOD (LOD/2).

First, the normality of each element level was tested by use of the Kolmogorov-Smirnov test. The results (Table 1) showed that the concentrations of the analytes were not normally distributed with the exception of $\mathrm{Al}, \mathrm{Si}, \mathrm{P}, \mathrm{Ca}, \mathrm{Zn}, \mathrm{Sr}$, $\mathrm{Cd}, \mathrm{Mn}$, and Se. Consequently, univariate analyses were conducted both with non-parametric techniques on unadjusted data and with parametric techniques on natural logtransformed data for all investigated elements (except for $\mathrm{Al}$, $\mathrm{Si}, \mathrm{P}, \mathrm{Ca}, \mathrm{Zn} \mathrm{Sr}, \mathrm{Cd}, \mathrm{Mn}$, and Se). In particular, Mann-Whitney tests and $t$ tests for independent samples were used to test the statistical significance of the differences in the median or mean levels of each element according to occupational scenario. Then, forward multiple linear regression analyses were run to evaluate the independent contributions of occupational scenario, gender, age, and BMI on the hair concentration of all analysed trace elements. In particular, in each model, the natural log-transformed value of the single hair element (except for $\mathrm{Al}, \mathrm{Si}, \mathrm{P}, \mathrm{Ca}, \mathrm{Zn} \mathrm{Sr}, \mathrm{Cd}, \mathrm{Mn}$, and $\mathrm{Se}$ ) was included as a dependent variable; independent variables were as follows: occupational scenario ("not working at Medeber" = " 0 " and "work at Medeber" $=1)$, gender $($ male $=0$, female $=1)$, age (years; a continuous variable), BMI (continuous variable). The significance level for all tests was $p \leq 0.05$ (two-tailed). Multiple linear regression analyses were run using a significance level of 0.05 for entry and 0.10 for removal from the model. The "goodness of fit" of the model was assessed using $R^{2}$ statistics. Finally, logistic regression analyses were performed to evaluate the contribution of each monitored major or trace element found in hair samples on the variable "work at Medeber". Backward elimination procedure was used for all logistic regression models ( $p<0.05$ was used as the threshold for removing a variable from each model). Work at Medeber (reference category was not work at Medeber) was used as the dependent variable of the models while the hair levels of each element, gender, age, and BMI as covariates.

\section{Results}

In Table 1, the isotope selection and the LOD for each monitored major and trace element together with the descriptive statistics of the levels of the elements in the scalp hair samples are reported. The concentrations of Te and $\mathrm{W}$ were found < LOD in most or all cases (100\% for $\mathrm{Tl}$ and $75 \%$ for W). For this reason, these elements were excluded from the statistical analysis together with $\mathrm{Nb}$ because its values were more than $20 \%$ of the results $<$ LOD.

The characteristics of the studied population are reported in Table 2. Approximately one-third of the population was female $(61.7 \%)$, and the average age was about 30 years old. Regarding the occupational scenario, just over half of the 
Table 1 Isotope selection, limit of determination (LOD; $\mu \mathrm{g} \mathrm{g}^{-1}$ ), and descriptive statistics of the levels of major and trace elements $\left(\mu \mathrm{g} \mathrm{g}^{-1}\right)$ in the scalp hair samples

\begin{tabular}{|c|c|c|c|c|c|}
\hline Element & LOD & $\%<\mathrm{LOD}$ & Arithmetic mean $\pm \mathrm{SD}$ & Median $\pm \mathrm{IQR}$ & Normal distribution of data ${ }^{a}$ \\
\hline${ }^{27} \mathrm{Al}$ & 0.1 & 11.7 & $40.85 \pm 23.10$ & $41.83 \pm 38.19$ & Yes \\
\hline${ }^{75}$ As & 0.01 & 13.3 & $0.058 \pm 0.069$ & $0.041 \pm 0.059$ & Yes, after ln-transformation \\
\hline${ }^{11} \mathrm{~B}$ & 0.4 & 16.7 & $1.85 \pm 2.11$ & $1.27 \pm 2.01$ & Yes, after ln-transformation \\
\hline${ }^{137} \mathrm{Ba}$ & 0.3 & 0 & $20.93 \pm 39.44$ & $7.23 \pm 6.94$ & Yes, after ln-transformation \\
\hline${ }^{9} \mathrm{Be}$ & 0.0004 & 1.7 & $0.0028 \pm 0.0021$ & $0.0020 \pm 0.0026$ & Yes, after ln-transformation \\
\hline${ }^{209} \mathrm{Bi}$ & 0.002 & 0 & $0.933 \pm 3.807$ & $0.018 \pm 0.063$ & Yes, after ln-transformation \\
\hline${ }^{44} \mathrm{Ca}$ & 20 & 0 & $2040 \pm 707$ & $2029 \pm 1025$ & Yes \\
\hline${ }^{112} \mathrm{Cd}$ & 0.001 & 0 & $0.078 \pm 0.077$ & $0.060 \pm 0.0801$ & Yes \\
\hline${ }^{140} \mathrm{Ce}$ & 0.0003 & 0 & $0.0075 \pm 0.0063$ & $0.0561 \pm 0.0394$ & Yes, after ln-transformation \\
\hline${ }^{59} \mathrm{Co}$ & 0.0008 & 0 & $0.122 \pm 0.107$ & $0.087 \pm 0.071$ & Yes, after ln-transformation \\
\hline${ }^{52} \mathrm{Cr}$ & 0.04 & 0 & $0.597 \pm 0.633$ & $0.391 \pm 0.331$ & Yes, after ln-transformation \\
\hline${ }^{133} \mathrm{Cs}$ & 0.0007 & 3.3 & $0.0033 \pm 0.0020$ & $0.0031 \pm 0.0017$ & Yes, after ln-transformation \\
\hline${ }^{65} \mathrm{Cu}$ & 0.07 & 0 & $15.402 \pm 10.740$ & $12.708 \pm 6.171$ & Yes, after ln-transformation \\
\hline${ }^{56} \mathrm{Fe}$ & 0.09 & 0 & $237.71 \pm 430.56$ & $115.05 \pm 128.16$ & Yes, after ln-transformation \\
\hline${ }^{71} \mathrm{Ga}$ & 0.001 & 0 & $0.020 \pm 0.0165$ & $0.016 \pm 0.009$ & Yes, after ln-transformation \\
\hline${ }^{39} \mathrm{~K}$ & 8 & 0 & $1,081 \pm 1646$ & $997 \pm 2753$ & Yes, after ln-transformation \\
\hline${ }^{139} \mathrm{La}$ & 0.0003 & 0 & $0.0336 \pm 0.0274$ & $0.0256 \pm 0.0170$ & Yes, after ln-transformation \\
\hline${ }^{7} \mathrm{Li}$ & 0.001 & 0 & $0.064 \pm 0.045$ & $0.049 \pm 0.053$ & Yes, after ln-transformation \\
\hline${ }^{24} \mathrm{Mg}$ & 2 & 0 & $249.7 \pm 131.4$ & $194.8 \pm 107.9$ & Yes, after ln-transformation \\
\hline${ }^{55} \mathrm{Mn}$ & 0.02 & 0 & $8.271 \pm 6.494$ & $6.755 \pm 6.302$ & Yes \\
\hline${ }^{98} \mathrm{Mo}$ & 0.0008 & 0 & $0.0729 \pm 0.0568$ & $0.0596 \pm 0.0422$ & Yes, after ln-transformation \\
\hline${ }^{23} \mathrm{Na}$ & 6 & 0 & $2553 \pm 227$ & $1596 \pm 2671$ & Yes, after ln-transformation \\
\hline${ }^{93} \mathrm{Nb}$ & 0.0004 & 28.3 & $0.0065 \pm 0.0136$ & $0.0012 \pm 0.0057$ & Yes, after ln-transformation \\
\hline${ }^{60} \mathrm{Ni}$ & 0.01 & 0 & $0.946 \pm 1.009$ & $0.653 \pm 0.739$ & Yes, after ln-transformation \\
\hline${ }^{31} \mathrm{P}$ & 3 & 0 & $157.1 \pm 22.1$ & $154.4 \pm 37.3$ & Yes \\
\hline${ }^{208} \mathrm{~Pb}$ & 0.02 & 0 & $6.089 \pm 8.870$ & $3.744 \pm 5.969$ & Yes, after ln-transformation \\
\hline${ }^{85} \mathrm{Rb}$ & 0.003 & 0 & $1.119 \pm 1.018$ & $0.693 \pm 1.538$ & Yes, after ln-transformation \\
\hline${ }^{121} \mathrm{Sb}$ & 0.0009 & 0 & $0.0163 \pm 0.0245$ & $0.0909 \pm 0.0842$ & Yes, after ln-transformation \\
\hline${ }^{76} \mathrm{Se}$ & 0.02 & 0 & $0.574 \pm 0.108$ & $0.581 \pm 0.148$ & Yes \\
\hline${ }^{28} \mathrm{Si}$ & 2 & 0 & $172.2 \pm 47.7$ & $165.6 \pm 62.4$ & Yes \\
\hline${ }^{118} \mathrm{Sn}$ & 0.0007 & 0 & $0.3231 \pm 0.2505$ & $0.2434 \pm 0.1796$ & Yes, after ln-transformation \\
\hline${ }^{88} \mathrm{Sr}$ & 0.04 & 0 & $8.464 \pm 5.396$ & $6.730 \pm 5.669$ & Yes \\
\hline${ }^{125} \mathrm{Te}$ & 0.006 & 100 & - & - & - \\
\hline${ }^{49} \mathrm{Ti}$ & 0.02 & 0 & $5.113 \pm 2.561$ & $4.527 \pm 1.284$ & Yes, after ln-transformation \\
\hline${ }^{205} \mathrm{Tl}$ & 0.0002 & 0 & $0.0033 \pm 0.0041$ & $0.0023 \pm 0.020$ & Yes, after ln-transformation \\
\hline${ }^{238} \mathrm{U}$ & 0.0001 & 0 & $0.0036 \pm 0.0032$ & $0.0025 \pm 0.0034$ & Yes, after ln-transformation \\
\hline${ }^{51} \mathrm{~V}$ & 0.0008 & 0 & $0.2906 \pm 0.1639$ & $0.2398 \pm 0.1346$ & Yes, after ln-transformation \\
\hline${ }^{182} \mathrm{~W}$ & 0.0007 & 75.0 & - & - & - \\
\hline${ }^{66} \mathrm{Zn}$ & 0.4 & 0 & $164.48 \pm 60.05$ & $159.74 \pm 63.86$ & Yes \\
\hline${ }^{90} \mathrm{Zr}$ & 0.002 & 0 & $0.160 \pm 0.259$ & $0.096 \pm 0.126$ & Yes, after ln-transformation \\
\hline
\end{tabular}

${ }^{a}$ According to Kolmogorov-Smirnov test individuals (53.3\%) worked at the Medeber market, while just under half of the individuals (46.7\%) did not work at Medeber and were employed in administrative companies far from Medeber. BMI mean value (20.57) corresponded to a "normal" ponderal status (normal ponderal status $=18.5-24.9$ ). Notice that only six out of the 60 participants were former smokers and the others never smokers. Thus, we decided not to consider this variable in the subsequent statistical analyses.
The results of the univariate statistical analysis according to occupational scenario are shown in Table 3, while the results of the forward multiple regression analyses are reported in Table 4. Significant differences were found in the mean levels of monitored elements according to the occupational scenario. Indeed, $\mathrm{Be}, \mathrm{B}, \mathrm{Cu}, \mathrm{Zn}, \mathrm{Mo}, \mathrm{Cd}, \mathrm{Sb}, \mathrm{Tl}, \mathrm{Pb}$, and Fe levels were significantly higher in subjects working at Medeber than those recovered from the others, with levels greater than about 1.5-2 
Table 2 Characteristics of the studied population

\begin{tabular}{lll}
\hline \multirow{2}{*}{ Gender } & & $n(\%)$ or mean \pm SD \\
& M & $37(61.7)$ \\
Work at Medeber & F & $23(38.3)$ \\
& Yes & $32(53.3)$ \\
Smoker & No & $28(46.7)$ \\
& Yes & $6(10.0)$ \\
Age & No & $54(90.0)$ \\
Body mass index (BMI) & & $29.7 \pm 8.5$ \\
& & $20.6 \pm 3.3$ \\
\hline
\end{tabular}

times in the exposed workers compared with not occupationally exposed individuals. In contrast, $\mathrm{Na}, \mathrm{K}$, and $\mathrm{Rb}$ were significantly lower (about 50\% less) in individuals working at Medeber than in the other group. Multivariate analyses confirmed that hair levels of $\mathrm{Bi}, \mathrm{Cu}, \mathrm{Fe}, \mathrm{Pb}, \mathrm{Rb}, \mathrm{Sb}$, and $\mathrm{Zn}$, were significantly increased in the individuals who work at Medeber. In particular, we found positive standardized regression coefficients for $\mathrm{Bi}(0.251), \mathrm{Cu}$ (0.338), $\mathrm{Fe}(0.281), \mathrm{Pb}$ (0.339), Sb (0.394), and $\mathrm{Zn}(0.273)$ and a negative coefficient for $\mathrm{Rb}(-0.214)$. In addition, multivariate models revealed a statistically significant independent influence of gender and age on some elemental content in hair samples. Indeed, the hair levels of $\mathrm{B}, \mathrm{Cd}, \mathrm{Pb}$, and $\mathrm{Tl}$ significantly increase as age increases. The results of the logistic regression analyses, performed to evaluate the contribution of each element' hair levels on work at Medeber, are shown in Table 5. Cu, Fe, K, $\mathrm{Pb}, \mathrm{Rb}, \mathrm{Sb}$, and $\mathrm{Zn}$ resulted significant indicators of "work at Medeber", with OR equal to $11.41,2.66,0.43,2.78,0.40$, 3.26 , and 1.02 , respectively.

Table 6 reports the results of the water samples analysis of two samples of local mineral water and one samples of Asmara tap water.

\section{Discussion}

The present study was aimed to evaluate the exposure profile of a group of Eritrean adults employed at the Medeber metal market by means of scalp hair analysis of 40 major and trace elements and comparison of the results with those recovered for a not-exposed group. In addition, we assessed the potential influence of gender, age, and BMI as confounding/interfering factors.

First of all, the hair levels of the 40 monitored elements resulted extremely heterogeneous, with a range varying from $0.0012 \pm 0.0057 \mu \mathrm{g} \mathrm{g}^{-1}$ for $\mathrm{Nb}$ to $2029 \pm 1025 \mu \mathrm{g} \mathrm{g}^{-1}$ for $\mathrm{Ca}$. Another relevant result consists of the fact that essential elements such as $\mathrm{Na}, \mathrm{Ca}, \mathrm{Mg}$, and $\mathrm{K}$ showed the highest concentrations. In addition, it is important to note that the results of toxic elements such as $\mathrm{Pb}, \mathrm{Cu}, \mathrm{Zn}, \mathrm{Ni}, \mathrm{Cd}$, and $\mathrm{Cr}$ were always detectable. Our results are in the same order of magnitude as those reported in previous studies performed in Asian, European, and American countries [23, 24, 27, 28, 41-43]. However, there are some differences in the mean values for each specific element. For example, in accordance with our results, Khalique et al. [41] found that $\mathrm{Ca}$ presented the highest concentration in the analysed scalp hair samples, but with mean concentrations (462 $\mathrm{\mu g} \mathrm{g}^{-1}$ for males and $870 \mu \mathrm{g} \mathrm{g}^{-1}$ for females) lower than those recovered in the present study. Similarly, Luo et al. [23] found that $\mathrm{Ca}$ had the highest levels among 33 investigated elements but recovered a median concentration equal to $300.50 \mu \mathrm{g} \mathrm{g}^{-1}$ that is much lower than the median values in our study (2029 $\mathrm{M} \mathrm{g} \mathrm{g}^{-1}$ ). These differences can be explained by the possible contribution of some interfering/confounding factors (in part discussed later) such as age, gender, occupational exposure, race/ethnicity, and geographical area of residence. For example, Skalny et al. [44, 45] found that both gender and geographical location significantly influence the hair content of trace and ultratrace elements in occupationally not-exposed adult populations. Similarly, other studies demonstrated that gender was a confounding factor of metal profiles in children hair $[46,47]$. Regarding the geographical area of residence, Luo et al. [23] noted that mean levels of inorganic elements in hair from different countries varied significantly. In addition, some differences can be attributed to the method used for sampling, treating, and analysing the scalp hair [48, 49]. In this regard, a systematic review on reference ranges of trace elements in human hair found that the steps of the methodological approach, including sample preparation, digestion, and analysis, differed in the revised papers and, for this reason, the reference values of hair minerals varied widely [49].

With respect to the occupational exposure, univariate analysis indicated that there were significant differences in the mean levels of several monitored elements: $\mathrm{Be}, \mathrm{B}, \mathrm{Cu}, \mathrm{Zn}$, $\mathrm{Mo}, \mathrm{Cd}, \mathrm{Sb}, \mathrm{Tl}, \mathrm{Pb}$, and Fe levels were significantly higher in subjects working at Medeber than those recovered from the others, while $\mathrm{Na}, \mathrm{K}$, and $\mathrm{Rb}$ were significantly lower in individuals working at Medeber than in the other group. Multivariate analyses confirmed that hair $\mathrm{Cu}, \mathrm{Zn}, \mathrm{Sb}, \mathrm{Pb}$, and $\mathrm{Fe}$ were significantly increased in the individuals who work at Medeber. These elements are typical constituents of materials processed in the Medeber market for making metal objects. Thus, it is presumed there is relevant airborne pollution at that site resulting in the intake of the same elements by the Medeber workers during working days. A previous study, carried out to compare the levels of some elements in the hair of industrial workers and controls working in the office, demonstrated that the concentrations of $\mathrm{Cd}, \mathrm{Cr}, \mathrm{Cu}, \mathrm{Mn}$, and $\mathrm{Ni}$ in the hair samples of foundry workers and $\mathrm{Cu}, \mathrm{Mn}$, and $\mathrm{Ni}$ in the workers of a workshop and match factory were higher with respect to those recovered in the hair of controls [50]. Another study [51], performed for evaluating exposure of workers 
Table 3 Univariate statistical analysis in the studied population according to the occupational scenario

\begin{tabular}{|c|c|c|c|c|c|c|}
\hline Element & $\begin{array}{l}\text { Not work at Medeber } \\
\text { Arithmetic mean } \pm \text { SD }\end{array}$ & Median $\pm \mathrm{IQR}$ & $\begin{array}{l}\text { Work at Medeber } \\
\text { Arithmetic mean } \pm \mathrm{SD}\end{array}$ & Median $\pm \mathrm{IQR}$ & $p$ value $^{\mathrm{a}}$ & $p$ value $^{\mathrm{b}}$ \\
\hline $\mathrm{Al}$ & $40.58 \pm 23.11$ & $41.84 \pm 39.20$ & $41.08 \pm 23.46$ & $41.06 \pm 40.45$ & 0.976 & 0.933 \\
\hline As & $0.040 \pm 0.031$ & $0.031 \pm 0.064$ & $0.074 \pm 0.088$ & $0.054 \pm 0.063$ & 0.100 & 0.090 \\
\hline $\mathrm{B}$ & $1.215 \pm 0.926$ & $1.003 \pm 1.627$ & $2.400 \pm 2.652$ & $1.654 \pm 2.711$ & 0.048 & 0.037 \\
\hline $\mathrm{Ba}$ & $19.25 \pm 42.92$ & $6.17 \pm 5.75$ & $22.50 \pm 36.57$ & $8.62 \pm 11.36$ & 0.031 & 0.176 \\
\hline $\mathrm{Be}$ & $0.0019 \pm 0.0011$ & $0.0016 \pm 0.0010$ & $0.0035 \pm 0.0025$ & $0.0033 \pm 0.0032$ & 0.012 & 0.016 \\
\hline $\mathrm{Bi}$ & $1.0634 \pm 5.0281$ & $0.0121 \pm 0.0306$ & $0.8194 \pm 2.3527$ & $0.0330 \pm 0.1209$ & 0.091 & 0.146 \\
\hline $\mathrm{Ca}$ & $2092 \pm 772$ & $1983 \pm 1297$ & $1994 \pm 653$ & $2029 \pm 924$ & 0.667 & 0.594 \\
\hline $\mathrm{Cd}$ & $0.053 \pm 0.082$ & $0.028 \pm 0.039$ & $0.100 \pm 0.066$ & $0.084 \pm 0.055$ & $<0.001$ & 0.018 \\
\hline $\mathrm{Ce}$ & $0.0688 \pm 0.0405$ & $0.0575 \pm 0.0377$ & $0.0794 \pm 0.0774$ & $0.0525 \pm 0.0439$ & 0.689 & 0.935 \\
\hline Co & $0.122 \pm 0.109$ & $0.080 \pm 0.076$ & $0.123 \pm 0.107$ & $0.088 \pm 0.066$ & 0.847 & 0.863 \\
\hline $\mathrm{Cr}$ & $0.475 \pm 0.427$ & $0.335 \pm 0.216$ & $0.703 \pm 0.761$ & $0.438 \pm 0.426$ & 0.100 & 0.102 \\
\hline Cs & $0.0036 \pm 0.0022$ & $0.0032 \pm 0.0030$ & $0.0032 \pm 0.0018$ & $0.0030 \pm 0.0017$ & 0.573 & 0.773 \\
\hline $\mathrm{Cu}$ & $12.295 \pm 4.815$ & $10.837 \pm 3.721$ & $18.120 \pm 13.528$ & $14.797 \pm 6.835$ & 0.001 & 0.004 \\
\hline $\mathrm{Fe}$ & $119.91 \pm 91.99$ & $94.75 \pm 80.20$ & $340.80 \pm 567.41$ & $166.23 \pm 219.87$ & 0.006 & 0.005 \\
\hline $\mathrm{Ga}$ & $0.018 \pm 0.012$ & $0.016 \pm 0.009$ & $0.021 \pm 0.020$ & $0.016 \pm 0.011$ & 0.824 & 0.763 \\
\hline $\mathrm{K}$ & $2284 \pm 1796$ & $1791 \pm 2844$ & $1378 \pm 1398$ & $8721 \pm 635$ & 0.032 & 0.028 \\
\hline $\mathrm{La}$ & $0.0314 \pm 0.0186$ & $0.0277 \pm 0.0188$ & $0.0355 \pm 0.0335$ & $0.0241 \pm 0.0177$ & 0.594 & 0.972 \\
\hline $\mathrm{Li}$ & $0.052 \pm 0.035$ & $0.047 \pm 0.026$ & $0.074 \pm 0.049$ & $0.066 \pm 0.076$ & 0.127 & 0.071 \\
\hline $\mathrm{Mg}$ & $234.6 \pm 122.1$ & $194.8 \pm 98.4$ & $262.4 \pm 139.4$ & $196.7 \pm 155.2$ & 0.646 & 0.366 \\
\hline $\mathrm{Mn}$ & $7.974 \pm 6.648$ & $6.559 \pm 6.225$ & $8.530 \pm 6.451$ & $6.842 \pm 6.244$ & 0.604 & 0.744 \\
\hline Mo & $0.0636 \pm 0.0657$ & $0.0458 \pm 0.0258$ & $0.0810 \pm 0.0473$ & $0.0663 \pm 0.0352$ & 0.004 & 0.026 \\
\hline $\mathrm{Na}$ & $3123 \pm 2731$ & $2019 \pm 3281$ & $2055 \pm 2261$ & $1111 \pm 1835$ & 0.042 & 0.039 \\
\hline $\mathrm{Ni}$ & $0.728 \pm 0.545$ & $0.519 \pm 0.699$ & $1.137 \pm 1.264$ & $0.663 \pm 1.088$ & 0.279 & 0.161 \\
\hline $\mathrm{P}$ & $161.3 \pm 18.9$ & $154.5 \pm 34.4$ & $153.4 \pm 24.3$ & $153.5 \pm 41.2$ & 0.110 & 0.125 \\
\hline $\mathrm{Pb}$ & $3.981 \pm 5.382$ & $2.533 \pm 4.250$ & $7.934 \pm 10.816$ & $4.671 \pm 5.571$ & 0.002 & 0.001 \\
\hline $\mathrm{Rb}$ & $1.465 \pm 1.172$ & $1.312 \pm 1.949$ & $0.815 \pm 0.758$ & $0.587 \pm 1.018$ & 0.024 & 0.025 \\
\hline $\mathrm{Sb}$ & $0.0606 \pm 0.3153$ & $0.0635 \pm 0.0606$ & $0.0871 \pm 0.0761$ & $0.1268 \pm 0.0777$ & $<0.001$ & 0.001 \\
\hline $\mathrm{Se}$ & $0.587 \pm 0.097$ & $0.590 \pm 0.134$ & $0.562 \pm 0.117$ & $0.573 \pm 0.175$ & 0.374 & 0.370 \\
\hline $\mathrm{Si}$ & $176.8 \pm 46.4$ & $172.7 \pm 68.4$ & $168.1 \pm 49.1$ & $162.3 \pm 60.0$ & 0.335 & 0.481 \\
\hline $\mathrm{Sn}$ & $0.3110 \pm 0.2762$ & $0.2382 \pm 0.1764$ & $0.3337 \pm 0.2296$ & $0.2539 \pm 0.2525$ & 0.382 & 0.352 \\
\hline $\mathrm{Sr}$ & $7.628 \pm 4.407$ & $6.244 \pm 6.104$ & $9.197 \pm 6.378$ & $6.965 \pm 5.488$ & 0.358 & 0.279 \\
\hline $\mathrm{Ti}$ & $4.788 \pm 1.149$ & $4.491 \pm 1.211$ & $5.398 \pm 3.339$ & $4.561 \pm 1.950$ & 0.988 & 0.666 \\
\hline $\mathrm{Tl}$ & $0.0026 \pm 0.0023$ & $0.0021 \pm 0.0015$ & $0.0040 \pm 0.0051$ & $0.0026 \pm 0.0022$ & 0.028 & 0.043 \\
\hline $\mathrm{U}$ & $0.0033 \pm 0.0035$ & $0.0021 \pm 0.0021$ & $0.0040 \pm 0.0029$ & $0.0026 \pm 0.0103$ & 0.236 & 0.259 \\
\hline V & $0.2954 \pm 0.1519$ & $0.2370 \pm 0.1525$ & $0.2864 \pm 0.1760$ & $0.2414 \pm 0.1377$ & 0.646 & 0.558 \\
\hline $\mathrm{Zn}$ & $141.77 \pm 38.34$ & $140.03 \pm 50.89$ & $184.36 \pm 68.62$ & $180.70 \pm 81.05$ & 0.008 & 0.005 \\
\hline $\mathrm{Zr}$ & $0.124 \pm 0.116$ & $0.077 \pm 0.101$ & $0.192 \pm 0.337$ & $0.103 \pm 0.124$ & 0.407 & 0.371 \\
\hline
\end{tabular}

${ }^{a}$ Not work at Medeber and work at Medeber groups were compared using Mann-Whitney test (unadjusted data)

${ }^{\mathrm{b}}$ Not work at Medeber and work at Medeber groups were compared using unpaired $t$ test (ln-transformed data, with the exception of $\mathrm{Al}$, Ca, Cd)

employed in tractor production (shop workers, thermal shop staff, steelmakers, and welders) by the measurement of $\mathrm{Ca}$, $\mathrm{Mg}, \mathrm{P}, \mathrm{Cu}, \mathrm{Fe}, \mathrm{Zn}, \mathrm{Al}, \mathrm{Mn}, \mathrm{Cr}, \mathrm{Ni}, \mathrm{Pb}$, and $\mathrm{Cd}$ concentrations in hair samples, found that the highest concentrations were for $\mathrm{Ca}, \mathrm{Mg}$, and $\mathrm{P}\left(995,66.8\right.$, and $182 \mathrm{mg} \mathrm{kg}^{-1}$, respectively). In addition, in the same study, steelmakers had higher Mn concentrations in their hair $\left(3.4 \mathrm{mg} \mathrm{kg}^{-1}\right)$, while welders presented the highest levels of $\mathrm{Fe}, \mathrm{P}, \mathrm{Zn}$, and $\mathrm{Cr}(26,393$, 205, and
$1 \mathrm{mg} \mathrm{kg}^{-1}$, respectively). To correctly discuss these results, we took into consideration the results of multiple regression analyses related to the influence of gender, age, and BMI on the hair levels of monitored elements and, thus, also on the occupational exposure profile. Multivariate analyses evidenced gender differences for several elements as shown in Table 5. The relevance of gender on the levels of environmental compounds in biological samples has already been established by 
Table 4 Significant predictors of monitored trace elements levels in hair samples identified by forward multiple linear regression models

\begin{tabular}{|c|c|c|c|c|c|c|}
\hline Element & Variable & $B^{\mathrm{a}}$ & $\mathrm{SE}^{\mathrm{b}}$ & $\beta^{\mathrm{c}}$ & $p$ & $\begin{array}{l}\text { Adjusted } R^{2} \text { of } \\
\text { the model }\end{array}$ \\
\hline B & $\begin{array}{l}\text { Constant } \\
\text { Age }\end{array}$ & $\begin{array}{l}-0.963 \\
0.037\end{array}$ & $\begin{array}{l}0.514 \\
0.017\end{array}$ & - & $\begin{array}{l}0.066 \\
0.031\end{array}$ & 0.064 \\
\hline $\mathrm{Be}$ & $\begin{array}{l}\text { Constant } \\
\text { Gender }\end{array}$ & $\begin{array}{l}-5.880 \\
-0.664\end{array}$ & $\begin{array}{l}0.116 \\
0.189\end{array}$ & $\begin{array}{l}- \\
-0.426\end{array}$ & $\begin{array}{l}<0.001 \\
0.001\end{array}$ & 0.167 \\
\hline \multirow[t]{2}{*}{$\mathrm{Bi}$} & $\begin{array}{l}\text { Constant } \\
\text { Gender }\end{array}$ & $\begin{array}{l}-4.670 \\
1.928\end{array}$ & $\begin{array}{l}0.462 \\
0.542\end{array}$ & $-\overline{0.430}$ & $\begin{array}{l}<0.001 \\
0.001\end{array}$ & 0.186 \\
\hline & Work at Medeber & 1.100 & 0.529 & 0.251 & 0.042 & \\
\hline $\mathrm{Cd}$ & $\begin{array}{l}\text { Constant } \\
\text { Age }\end{array}$ & $\begin{array}{l}-0.036 \\
0.004\end{array}$ & $\begin{array}{l}0.034 \\
0.001\end{array}$ & $\begin{array}{l}- \\
0.427\end{array}$ & $\begin{array}{l}0.300 \\
0.001\end{array}$ & 0.168 \\
\hline $\mathrm{Cr}$ & $\begin{array}{l}\text { Constant } \\
\text { Gender }\end{array}$ & $\begin{array}{l}-0.630 \\
-0.449\end{array}$ & $\begin{array}{l}0.112 \\
0.182\end{array}$ & $\begin{array}{l}- \\
-0.314\end{array}$ & $\begin{array}{l}<0.001 \\
0.016\end{array}$ & 0.082 \\
\hline $\mathrm{Cu}$ & $\begin{array}{l}\text { Constant } \\
\text { Work at Medeber }\end{array}$ & $\begin{array}{l}2.487 \\
0.277\end{array}$ & $\begin{array}{l}0.077 \\
0.103\end{array}$ & - & $\begin{array}{l}<0.001 \\
0.009\end{array}$ & 0.099 \\
\hline \multirow[t]{2}{*}{$\mathrm{Fe}$} & $\begin{array}{l}\text { Constant } \\
\text { Gender }\end{array}$ & $\begin{array}{l}4.912 \\
-0.612\end{array}$ & $\begin{array}{l}0.186 \\
0.218\end{array}$ & -0.337 & $\begin{array}{l}<0.001 \\
0.007\end{array}$ & 0.193 \\
\hline & Work at Medeber & 0.497 & 0.213 & 0.281 & 0.023 & \\
\hline K & $\begin{array}{l}\text { Constant } \\
\text { Gender }\end{array}$ & $\begin{array}{l}6.382 \\
1.538\end{array}$ & $\begin{array}{l}0.147 \\
0.238\end{array}$ & $\overline{-}-653$ & $\begin{array}{l}<0.001 \\
<0.001\end{array}$ & 0.417 \\
\hline Mo & $\begin{array}{l}\text { Constant } \\
\text { Gender }\end{array}$ & $\begin{array}{l}-2.639 \\
-0.317\end{array}$ & $\begin{array}{l}0.083 \\
0.134\end{array}$ & $\begin{array}{l}- \\
-0.302\end{array}$ & $\begin{array}{l}<0.001 \\
0.021\end{array}$ & 0.075 \\
\hline $\mathrm{Na}$ & $\begin{array}{l}\text { Constant } \\
\text { Gender }\end{array}$ & $\begin{array}{l}6.940 \\
1.211\end{array}$ & $\begin{array}{l}0.116 \\
0.189\end{array}$ & - & $\begin{array}{l}<0.001 \\
<0.001\end{array}$ & 0.413 \\
\hline $\mathrm{P}$ & $\begin{array}{l}\text { Constant } \\
\text { Gender }\end{array}$ & $\begin{array}{l}152.537 \\
12.672\end{array}$ & $\begin{array}{l}3.628 \\
5.890\end{array}$ & - & $\begin{array}{l}<0.001 \\
0.036\end{array}$ & 0.060 \\
\hline $\mathrm{Pb}$ & $\begin{array}{l}\text { Constant } \\
\text { Age } \\
\text { Work at Medeber }\end{array}$ & $\begin{array}{l}-0.715 \\
0.049 \\
0.810\end{array}$ & $\begin{array}{l}0.502 \\
0.017 \\
0.279\end{array}$ & $\begin{array}{l}- \\
0.348 \\
0.339\end{array}$ & $\begin{array}{l}0.160 \\
0.004 \\
0.005\end{array}$ & 0.258 \\
\hline \multirow[t]{2}{*}{$\mathrm{Rb}$} & $\begin{array}{l}\text { Constant } \\
\text { Gender }\end{array}$ & $\begin{array}{l}-0.630 \\
1.339\end{array}$ & $\begin{array}{l}0.195 \\
0.229\end{array}$ & $-\overline{0}-596$ & $\begin{array}{l}0.002 \\
<0.001\end{array}$ & 0.420 \\
\hline & Work at Medeber & -0.469 & 0.224 & -0.214 & 0.041 & \\
\hline $\mathrm{Sb}$ & $\begin{array}{l}\text { Constant } \\
\text { Work at Medeber }\end{array}$ & $\begin{array}{l}-2.673 \\
0.696\end{array}$ & $\begin{array}{l}0.161 \\
0.217\end{array}$ & - & $\begin{array}{l}<0.001 \\
0.002\end{array}$ & 0.140 \\
\hline $\mathrm{Sn}$ & $\begin{array}{l}\text { Constant } \\
\text { Gender }\end{array}$ & $\begin{array}{l}-1.521 \\
0.469\end{array}$ & $\begin{array}{l}0.106 \\
0.173\end{array}$ & $\begin{array}{l}- \\
0.341\end{array}$ & $\begin{array}{l}<0.001 \\
0.009\end{array}$ & 0.100 \\
\hline $\mathrm{Tl}$ & $\begin{array}{l}\text { Constant } \\
\text { Age }\end{array}$ & $\begin{array}{l}-7.072 \\
0.037\end{array}$ & $\begin{array}{l}0.284 \\
0.009\end{array}$ & $\begin{array}{l}- \\
0.475\end{array}$ & $\begin{array}{l}<0.001 \\
0.000\end{array}$ & 0.211 \\
\hline $\mathrm{U}$ & Constant & $\begin{array}{l}-6.689 \\
-0.886\end{array}$ & $\begin{array}{l}0.522 \\
0.169\end{array}$ & -0.575 & $\begin{array}{l}<0.001 \\
<0.001\end{array}$ & 0.327 \\
\hline & BMI & 0.055 & 0.025 & 0.238 & 0.034 & \\
\hline $\mathrm{Zn}$ & $\begin{array}{l}\text { Constant } \\
\text { Gender }\end{array}$ & $\begin{array}{l}165.789 \\
-44.546\end{array}$ & $\begin{array}{l}12.375 \\
14.524\end{array}$ & $\begin{array}{l}- \\
-0.365\end{array}$ & $\begin{array}{l}<0.001 \\
0.003\end{array}$ & 0.211 \\
\hline & Work at Medeber & 32.488 & 14.171 & 0.273 & 0.026 & \\
\hline
\end{tabular}

No variable entered in the models run for $\mathrm{Al}, \mathrm{As}, \mathrm{Ba}, \mathrm{Ca}, \mathrm{Ce}, \mathrm{Co}, \mathrm{Cs}, \mathrm{Ga}, \mathrm{La}, \mathrm{Li}, \mathrm{Mg}, \mathrm{Mn}, \mathrm{Ni}, \mathrm{Se}, \mathrm{Si}, \mathrm{Sr}, \mathrm{Ti}, \mathrm{V}$, and $\mathrm{Zr}$

${ }^{\mathrm{a}} B$, non-standardized regression coefficients

${ }^{\mathrm{b}} \mathrm{SE}$, standard error

${ }^{\mathrm{c}} \beta$, standardized regression coefficients

${ }^{\mathrm{d}}$ Variables considered: work at Medeber (Yes vs. No; No represented the reference category), gender (female vs. male; male represented the reference category), age, and body mass index (BMI) (continuous variables)

Constant, estimated intercept value other researchers $[23,24,41,42,52-54]$. These differences can be in part attributed to genetic and hormonal factors, which can interfere with the absorption, distribution, transformation, and excretion of environmental compounds after their 
Table 5 Major and trace elements indicators of "work at Medeber" evaluated by logistic regression analyses

\begin{tabular}{llllcccc}
\hline $\begin{array}{l}\text { Major or trace } \\
\text { element }\end{array}$ & $\begin{array}{c}\text { Adjusted } \\
\text { OR }\end{array}$ & $95 \% \mathrm{CI}$ & $p$ & $\begin{array}{c}\text { Cox and Snell } \\
R \text { square }\end{array}$ & $\begin{array}{c}\text { Nagelkerke } \\
R \text { square }\end{array}$ & $\begin{array}{c}\text { McFadden } \\
R \text { square }\end{array}$ & $\begin{array}{c}p \text { for the } \\
\text { model }\end{array}$ \\
$\mathrm{Cu}$ & 11.41 & $1.33-98.29$ & 0.027 & 0.228 & 0.301 & 0.186 & 0.005 \\
$\mathrm{Fe}$ & 2.66 & $1.13-6.29$ & 0.026 & 0.208 & 0.279 & 0.170 \\
$\mathrm{~K}$ & 0.43 & $0.20-0.95$ & 0.037 & 0.194 & 0.260 & 0.157 & 0.009 \\
$\mathrm{~Pb}$ & 2.78 & $1.40-5.54$ & 0.004 & 0.275 & 0.368 & 0.234 \\
$\mathrm{Rb}$ & 0.40 & $0.18-0.89$ & 0.025 & 0.205 & 0.275 & 0.167 \\
$\mathrm{Sb}$ & 3.26 & $1.32-8.05$ & 0.010 & 0.250 & 0.334 & 0.209 & 0.010 \\
$\mathrm{Zn}$ & 1.02 & $1.00-1.03$ & 0.019 & 0.228 & 0.305 & 0.001 \\
\hline
\end{tabular}

Al, As, B, Ba, Be, Bi, Ca, Cd, Ce, Co, Cr, Cs, Ga, La, Li, Mg, Mn, Mo, Na, Ni, P, Se, Si, Sn, Sr, Ti, Tl, U, V, and Zr resulted not statistically significant indicators of work at Medeber (dependent variable of the models; reference category was not work at Medeber)

${ }^{\mathrm{a}} \mathrm{OR}$, odds ratio adjusted for each major or trace elements as well as for gender, age, and body mass index (BMI)

intake, as hypothesized previously when gender differences in human biomonitoring studies emerged [52]. In addition, these differences can also be explained by the different diets and eating habits of males and females [43]. It is important to note that gender is not considered in the periodic surveillance of workers based on biomonitoring for assessing occupational exposure.

It is important to highlight that during the monitoring campaigns, we observed a total lack of health protection strategies for the Medeber workers; they do not use any collective or individual protective equipment. This observation confirms the assumption that the studied occupational scenario significantly increases the exposure to and the consequent intake of heavy metals during the working activities. This is of particular concern because the exposure to trace/toxic metals is related to possible risks for human health. For example, Mehra and Juneja [55] demonstrated significant correlations between several health disorders or diseases and the levels of some trace elements in hair and various biopsy materials. In particular, they identified a significant relationship between skin disease and $\mathrm{Cr}, \mathrm{Mn}, \mathrm{Fe}$, and/or $\mathrm{Cu}$; chest pain and $\mathrm{Pb}$; hypertension and $\mathrm{Cu}$ and/or $\mathrm{Mn}$; mental stress and $\mathrm{Mn}, \mathrm{Ni}, \mathrm{Cu}$, and/or $\mathrm{Zn}$; liver problems and $\mathrm{Ni}$; indigestion and $\mathrm{Cr}$ and/or $\mathrm{Ni}$; diabetes and $\mathrm{Cr}, \mathrm{Mn}$, and/or $\mathrm{Ni}$; tuberculosis and $\mathrm{Zn}$; and breathing disorders and $\mathrm{Cr}, \mathrm{Mn}, \mathrm{Fe}, \mathrm{Ni}$, and/or $\mathrm{Zn}$.
Table 6 Results of the water samples analysis performed by following Italian Official methods for the analysis of drinking water [40]

\begin{tabular}{lllll}
\hline Parameter $\left(\mathrm{mg} \mathrm{L}^{-1}\right)$ & Mineral water n.1 & Mineral water n.2 & Tap water & LOD \\
$\mathrm{SiO}_{2}$ & 0.72 & 0.48 & 0.57 & 0.04 \\
$\mathrm{Na}$ & 2.7 & 3.6 & 11 & 0.1 \\
$\mathrm{~K}$ & 0.2 & 0.1 & 3.6 & 0.2 \\
$\mathrm{Ca}$ & 6.4 & 4.4 & 33 & 0.1 \\
$\mathrm{Mg}$ & 1.2 & 0.8 & 10 & 0.1 \\
$\mathrm{Fe}$ & $<0.1$ & $<0.1$ & $<0.1$ & 0.1 \\
$\mathrm{P}$ & $<0.1$ & $<0.1$ & $<0.1$ & 0.1 \\
$\mathrm{Sr}$ & 0.01 & 0.01 & 0.02 & 0.01 \\
$\mathrm{Li}$ & $<0.01$ & $<0.01$ & 0.05 & 0.01 \\
$\mathrm{Al}$ & $<0.1$ & $<0.1$ & $<0.1$ & 0.1 \\
$\mathrm{Sb}$ & $<0.0005$ & $<0.0005$ & $<0.0005$ & 0.0005 \\
$\mathrm{As}$ & $<0.001$ & $<0.001$ & 0.001 & 0.001 \\
$\mathrm{Ba}$ & $<0.01$ & $<0.01$ & 0.04 & 0.01 \\
$\mathrm{~B}$ & $<0.1$ & $<0.1$ & $<0.1$ & 0.1 \\
$\mathrm{Cd}$ & $<0.0003$ & $<0.0003$ & $<0.0003$ & 0.0003 \\
$\mathrm{Cr}$ & $<0.005$ & $<0.005$ & $<0.005$ & 0.005 \\
$\mathrm{Cu}$ & $<0.01$ & $<0.01$ & $<0.01$ & 0.01 \\
$\mathrm{~Pb}$ & $<0.001$ & $<0.001$ & $<0.001$ & 0.001 \\
$\mathrm{Mn}$ & $<0.01$ & $<0.01$ & $<0.01$ & 0.01 \\
$\mathrm{Ni}$ & $<0.002$ & $<0.002$ & $<0.002$ & 0.002 \\
$\mathrm{Se}$ & $<0.001$ & $<0.001$ & $<0.001$ & 0.001 \\
\hline & & &
\end{tabular}


Regarding age, multivariate analyses partially confirmed the results of the univariate analyses. In particular, a positive correlation was confirmed for $\mathrm{B}, \mathrm{Cd}, \mathrm{Tl}$, and $\mathrm{Pb}$. Accordingly, Luo et al. [23] reported a tendency for $\mathrm{Tl}$ to accumulate in the hair of older studied subjects, indicating a plausible metabolic retention linked to the ageing process. In contrast, the same authors reported a significant reduction of the levels of $B$ and $a$ lack of change for $\mathrm{Pb}$ levels. These differences could be related to other predictors that we did not investigate that can affect the concentrations of hair elements, such as race and food and water intake. In this context, our informal questions about dietary habits confirmed that the main meals of the participants are meat based. Regarding the contribution of water ingestion on elements intake, we analysed the tap water supplied in the Asmara area and the unique two bottled waters available in the region. The results, reported in Table 6, show that all the three analysed water sources have a very low content of minerals, and trace elements are always below the LOD. These results are indicative of low impact of drinking water to exposure routes for monitored individuals.

The present study has some limitations. First, this is a cross-sectional study; thus, it does not permit an evaluation over time. In addition, the number of participants is limited. However, it is important to note that there is a lack of data on developing countries and, to our knowledge, this is the first human biomonitoring study performed on Eritrean individuals by the use of scalp hair samples. In addition, we were not able to analyse the air quality of the studied areas because the portable analyser, first used at Medeber, has stopped working due to excess airborne dust and it was no longer possible to continue air sampling and analysis.

\section{Conclusions}

The results of the present study, performed on a sample of Eritrean adults, evidenced relevant differences between subjects working at Medeber metal market and controls, with significantly higher levels of some heavy metals in the hair of those individuals employed in the metal market. In particular, metal workers showed significantly higher levels of $\mathrm{Cu}, \mathrm{Zn}, \mathrm{Sb}, \mathrm{Pb}$, and $\mathrm{Fe}$, all contained in the raw material used in the market and potential toxic for human health. This finding is strictly related to the absence of any collective or individual protection equipment used by Medeber workers, which we directly observed. These results reveal the need for more accurate and routine biomonitoring surveys and health promotion campaigns for both local decision-makers and workers in order to increase health promotion and safety in the metal market.

In addition, age and gender were significant independent predictors of hair levels of some elements and, thus, these factors should be taken into consideration when performing biomonitoring surveillance activities on exposed workers.
Funding Information The study was funded by the authors and their institution.

\section{Compliance with Ethical Standards}

This study was approved by the Minister of Health of Eritrea through acknowledgement of the ASS.ITER. Onlus, within the "Medeber project" and it was conducted in accordance with the Declaration of Helsinki.

Conflict of Interest The authors declare that they have no conflict of interest.

\section{References}

1. Center for Disease and Control (2009) Fourth national report on human exposure to environmental chemicals. http://www.cdc.gov/ exposurereport.

2. World Health Organization (2010) WHO human health risk assessment toolkit: chemical hazards. IPCS harmonization project document; no.8. http://www.who. int/ipcs/publications/methods/ harmonization/toolkit.pdf. Accessed 10 July 2019

3. Protano C, Andreoli R, Manini P, Vitali M (2012) Urinary trans, trans-muconic acid and S-phenylmercapturic acid are indicative of exposure to urban benzene pollution during childhood. Sci Total Environ 435-436:115-123. https://doi.org/10.1016/j.scitotenv. 2012.07.004

4. Andreoli R, Spatari G, Pigini D, Poli D, Banda I, Goldoni M, Riccelli MG, Petyx M, Protano C, Vitali M, Barbaro M, Mutti A (2015) Urinary biomarkers of exposure and of oxidative damage in children exposed to low airborne concentrations of benzene. Environ Res 142:264-272. https://doi.org/10.1016/j.envres.2015. 07.003

5. Zidek A, Macey K, MacKinnon L, Patel M, Poddalgoda D, Zhang Y (2017) A review of human biomonitoring data used in regulatory risk assessment under Canada's Chemicals Management Program. Int J Hyg Environ Health 220(2 Pt A):167-178. https://doi.org/10. 1016/j.jiheh.2016.10.007

6. Barnett-Itzhaki Z, Esteban López M, Puttaswamy N, Berman T (2018) A review of human biomonitoring in selected Southeast Asian countries. Environ Int 116:156-164. https://doi.org/10. 1016/j.envint.2018.03.046

7. Moretto A (2015) Exposure assessment for chemical and physical agents. Handb Clin Neurol 131:47-59. https://doi.org/10.1016/ B978-0-444-62627-1.00004-4

8. Heibati B, Godri Pollitt KJ, Charati JY, Ducatman A, Shokrzadeh M, Karimi A, Mohammadyan M (2018) Biomonitoring-based exposure assessment of benzene, toluene, ethylbenzene and xylene among workers at petroleum distribution facilities. Ecotoxicol Environ Saf 149:19-25. https://doi.org/10.1016/j.ecoenv.2017.10. 070

9. Protano C, Guidotti M, Manini P, Petyx M, La Torre G, Vitali M (2010) Benzene exposure in childhood: role of living environments and assessment of available tools. Environ Int 36:779-787. https:// doi.org/10.1016/j.envint.2010.06.003

10. Andreoli R, Protano C, Manini P, De Palma G, Goldoni M, Petyx M, Rondinone BM, Vitali M, Mutti A (2012) Association between environmental exposure to benzene and oxidative damage to nucleic acids in children. Med Lav 103:324-337

11. Stojsavljević A, Borković-Mitić S, Vujotić L, Grujičić D, GavrovićJankulović M, Manojlović D (2019) The human biomonitoring study in Serbia: background levels for arsenic, cadmium, lead, thorium and uranium in the whole blood of adult Serbian population. 
Ecotoxicol Environ Saf 169:402-409. https://doi.org/10.1016/j. ecoenv.2018.11.043

12. Mehra R, Juneja M (2003) Adverse health effects in workers exposed to trace/toxic metals at workplace. Indian J Biochem Biophys 40:131-135

13. Boumba VA, Ziavrou KS, Vougiouklakis T (2006) Hair as a biological indicator of drug use, drug abuse or chronic exposure to environmental toxicants. Int J Toxicol 25:143-163

14. Pozebon D, Scheffler GL, Dressler VL (2017) Elemental hair analysis: a review of procedures and applications. Anal Chim Acta 992: 1-23. https://doi.org/10.1016/j.aca.2017.09.017

15. Appenzeller BM, Tsatsakis AM (2012) Hair analysis for biomonitoring of environmental and occupational exposure to organic pollutants: state of the art, critical review and future needs. Toxicol Lett 210:119-140. https://doi.org/10.1016/j.toxlet.2011.10.021

16. Foo SC, Khoo NY, Heng A, Chua LH, Chia SE, Ong CN, Ngim $\mathrm{CH}$, Jeyaratnam J (1993) Metals in hair as biological indices for exposure. Int Arch Occup Environ Health 65:83-86. https://doi.org/ 10.1007/BF00381312

17. Kokkinaki A, Kokkinakis M, Kavvalakis MP, Tzatzarakis MN, Alegakis AK, Maravgakis G, Babatsikou F, Fragkiadakis GA, Tsatsakis AM (2014) Biomonitoring of dialkylphosphate metabolites (DAPs) in urine and hair samples of sprayers and rural residents of Crete, Greece. Environ Res 134:181-187. https://doi.org/ 10.1016/j.envres.2014.07.012

18. Appenzeller BMR, Hardy EM, Grova N, Chata C, Faÿs F, Briand O, Schroeder H, Duca RC (2017) Hair analysis for the biomonitoring of pesticide exposure: comparison with blood and urine in a rat model. Arch Toxicol 91:2813-2825. https://doi.org/10.1007/ s00204-016-1910-9

19. Liu LJ, Chen XC, Fu JP, Qing X, Huang JQ, Han JL (2019) Male workers' exposure characteristics of $\Sigma \mathrm{PCDD} / \mathrm{F}$ from a municipal solid waste incinerator in south China through hair analysis. Ecotoxicol Environ Saf 178:105-112. https://doi.org/10.1016/j. ecoenv.2019.04.011

20. Karzi V, Tzatzarakis MN, Vakonaki E, Alegakis T, Katsikantami I, Sifakis S, Rizos A, Tsatsakis AM (2018) Biomonitoring of bisphenol A, triclosan and perfluorooctanoic acid in hair samples of children and adults. J Appl Toxicol 38:1144-1152. https://doi. org/10.1002/jat.3627

21. Teresa M, Vasconcelos SD, Tavares HMF (1997) Trace element concentrations in blood and hair of young apprentices of a technical-professional school. Sci Total Environ 205:189-199. https://doi.org/10.1016/S0048-9697(97)00208-8

22. Czerny B, Krupka K, Ożarowski M, Seremak-Mrozikiewicz A (2014) Screening of trace elements in hair of the female population with different types of cancers in Wielkopolska region of Poland. Sci World J 953181. https://doi.org/10.1155/2014/953181

23. Luo R, Zhuo X, Ma D (2014) Determination of 33 elements in scalp hair samples from inhabitants of a mountain village of Tonglu city, China. Ecotoxicol Environ Saf 104:215-219. https://doi.org/10. 1016/j.ecoenv.2014.03.006

24. Zhu Y, Wang Y, Meng F, Li L, Wu S, Mei X, Li H, Zhang G, Wu D (2018) Distribution of metal and metalloid elements in human scalp hair in Taiyuan, China. Ecotoxicol Environ Saf 148:538-545. https://doi.org/10.1016/j.ecoenv.2017.10.073

25. Morton J, Carolan VA, Gardiner PHE (2002) Removal of exogenously bound elements from human hair by various washing procedures and determination by inductively coupled plasma mass spectrometry. Anal Chim Acta 455:23-34. https://doi.org/10. 1016/S0003-2670(01)01578-1

26. Reiss B, Simpson CD, Baker MG, Stover B, Sheppard L, Seixas NS (2016) Hair manganese as an exposure biomarker among welders. Ann Occup Hyg 60:139-149. https://doi.org/10.1093/annhyg/ mev064
27. Skalny AV, Kaminskaya GA, Krekesheva TI, Abikenova SK, Skalnaya MG, Bykov AT, Tinkov AA (2018) Assessment of hair metal levels in aluminium plant workers using scalp hair ICP-DRCMS analysis. J Trace Elem Med Biol 50:658-663. https://doi.org/ 10.1016/j.jtemb.2018.06.014

28. Skalny AV, Kaminskaya GA, Krekesheva TI, Abikenova SK, Skalnaya MG, Berezkina ES, Grabeklis AR, Tinkov AA (2017) The level of toxic and essential trace elements in hair of petrochemical workers involved in different technological processes. Environ Sci Pollut Res Int 24:5576-5584. https://doi.org/10.1007/s11356016-8315-4

29. Nouioui MA, Araoud M, Milliand ML, Bessueille-Barbier F, Amira D, Ayouni-Derouiche L, Hedhili A (2018) Evaluation of the status and the relationship between essential and toxic elements in the hair of occupationally exposed workers. Environ Monit Assess 190:731-728. https://doi.org/10.1007/s10661-018-7088-2

30. Sukumar A (2002) Factors influencing levels of trace elements in human hair. Rev Environ Contam Toxicol 175:47-78

31. Antonucci A, Vitali M, Avino P, Manigrasso M, Protano C (2016) Sensitive multiresidue method by HS-SPME/GC-MS for 10 volatile organic compounds in urine matrix: a new tool for biomonitoring studies on children. Anal Bioanal Chem 408:789-5800. https:// doi.org/10.1007/s00216-016-9682-x

32. Astolfi ML, Marconi E, Protano C, Vitali M, Schiavi E, Mastromarino P, Canepari S (2018) Optimization and validation of a fast digestion method for the determination of major and trace elements in breast milk by ICP-MS. Anal Chim Acta 1040:49-62. https://doi.org/10.1016/j.aca.2018.07.037

33. Mussie Tesfagiorgis G (2010) Eritrea ABC-CLIO. LLC, Santa Barbara, California

34. Chojnacka K, Michalak I, Zielińska A, Górecka H, Górecki H (2010) Inter-relationship between elements in human hair: the effect of gender. Ecotoxicol Environ Saf 73:2022-2028. https://doi.org/ 10.1016/j.ecoenv.2010.09.004

35. Szynkowska MI, Marcinek M, Pawlaczyk A, Albińska J (2015) Human hair analysis in relation to similar environmental and occupational exposure. Environ Toxicol Pharmacol 40:402-408. https:// doi.org/10.1016/j.etap.2015.07.005

36. Astolfi ML, Protano C, Schiavi E, Marconi E, Capobianco D, Massimi L, Ristorini M, Baldassarre ME, Laforgia N, Vitali M, Canepari S, Mastromarino P (2019) A prophylactic multi-strain probiotic treatment to reduce the absorption of toxic elements: invitro study and biomonitoring of breast milk and infant stools. Environment Int 130:104818. https://doi.org/10.1016/j.envint. 2019.05.012

37. Campopiano A, Cannizzaro A, Angelosanto F, Astolfi ML, Ramires D, Olori A, Canepari S, Iavicoli S (2014) Dissolution of glass wool, rock wool and alkaline earth silicate wool: morphological and chemical changes in fibers. Regul Toxicol Pharmacol 70: 393-406. https://doi.org/10.1016/j.yrtph.2014.05.023

38. Astolfi ML, Di Filippo P, Gentili A, Canepari S (2017) Semiautomatic sequential extraction of polycyclic aromatic hydrocarbons and elemental bio-accessible fraction by accelerated solvent extraction on a single particulate matter sample. Talanta 174: 838-844. https://doi.org/10.1016/j.talanta.2017.06.072

39. Conti ME, Canepari S, Finoia MG, Mele G, Astolfi ML (2018) Characterization of Italian multifloral honeys on the basis of their mineral content and some typical quality parameters. J Food Compost Anal 74:102-113. https://doi.org/10.1016/j.jfca.2018.09. 002

40. National Institute of Health of Italy (2007) Metodi analitici di riferimento per le acque destinate al consumo umano ai sensi del DL.vo 31/2001. Metodi chimici. Rapporti ISTISAN 07/31

41. Khalique A, Ahmad S, Anjum T, Jaffar M, Shah MH, Shaheen N, Tariq SR, Manzoor S (2005) A comparative study based on gender 
and age dependence of selected metals in scalp hair. Environ Monit Assess 104:45-57

42. Dunicz-Sokolowska A, Długaszek M, Radomska K, Wlaźlak E, Surkont G, Graczyk A (2007) Contents of bioelements and toxic metals in the Polish population determined by hair analysis. Part III. Adults aged 20 to 40 years. Magnes Res 20:43-52

43. Kumakli H, Duncan AV, McDaniel K, Mehari TF, Stephenson J, Maple L, Crawford Z, Macemore CL, Babyak CM, Fakayode SO (2017) Environmental biomonitoring of essential and toxic elements in human scalp hair using accelerated microwave-assisted sample digestion and inductively coupled plasma optical emission spectroscopy. Chemosphere. 174:708-715. https://doi.org/10.1016/ j.chemosphere.2017.02.032

44. Skalny AV, Skalnaya MG, Grabeklis AR, Berezkina ES, Serebryansky EP, Demidov VA, Lobanova YN, Gryazeva IV, Skalny AA, Skalnaya OA, Tinkov AA (2017) Comparative analysis and the coverage intervals of hair rare metal content in two Russian industrial centres. Int J Environ Anl Ch 97:520-533. https://doi.org/10.1080/03067319.2017.1328061

45. Skalny AV, Skalnaya MG, Tinkov AA, Serebryansky EP, Demidov VA, Lobanova YN, Grabeklis AR, Berezkina ES, Gryazeva IV, Skalny AA, Nikonorov AA (2015) Reference values of hair toxic trace elements content in occupationally non-exposed Russian population. Environ Toxicol Pharmacol 40:18-21. https://doi.org/10. 1016/j.etap.2015.05.004

46. Tamburo E, Varrica D, Dongarrà G (2016) Gender as a key factor in trace metal and metalloid content of human scalp hair. A multi-site study. Sci Total Environ 573:996-1002. https://doi.org/10.1016/j. scitotenv.2016.08.178

47. Dongarrà G, Lombardo $M$, Tamburo E, Varrica D, Cibella F, Cuttitta G (2011) Concentration and reference interval of trace elements in human hair from students living in Palermo, Sicily (Italy). Environ Toxicol Pharmacol 32:27-34. https://doi.org/10.1016/j. etap.2011.03.003
48. Kosanovic M, Jokanovic M (2011) Quantitative analysis of toxic and essential elements in human hair. Clinical validity of results. Environ Monit Assess 174:635-643. https://doi.org/10.1007/ s10661-010-1484-6

49. Mikulewicz M, Chojnacka K, Gedrange T, Górecki H (2013) Reference values of elements in human hair: a systematic review. Environ Toxicol Pharmacol 36:1077-1086. https://doi.org/10. 1016/j.etap.2013.09.012

50. Sukumar A, Subramanian R (2000) Elements in the hair of workers at a workshop, foundry, and match factory. Biol Trace Elem Res 77: 139-147. https://doi.org/10.1385/BTER:77:2:139

51. Vinnikov D, Semizhon S, Rybina T, Zaitsev V, Pleshkova A, Rybina A (2018) Occupational exposure to metals and other elements in the tractor production. PLoS One 13:e0208932. https:// doi.org/10.1371/journal.pone.0208932

52. Protano C, Astolfi ML, Canepari S, Vitali M (2016) Urinary levels of trace elements among primary school-aged children from Italy: the contribution of smoking habits of family members. Sci Total Environ 557-558:378-385. https://doi.org/10.1016/j.scitotenv. 2016.03.073

53. Liang G, Pan L, Liu X (2017) Assessment of typical heavy metals in human hair of different age groups and foodstuffs in Beijing, China. Int J Environ Res Public Health 14:E914. https://doi.org/ 10.3390/ijerph14080914

54. Protano C, Canepari S, Astolfi ML, D’Onorio De Meo S, Vitali M (2018) Urinary reference ranges and exposure profile for lithium among an Italian paediatric population. Sci Total Environ 619-620: 58-64. https://doi.org/10.1016/j.scitotenv.2017.11.090

55. Mehra R, Juneja M (2005) Elements in scalp hair and nails indicating metal body burden in polluted environment. J Sci Ind Res 64: $119-124$

Publisher's Note Springer Nature remains neutral with regard to jurisdictional claims in published maps and institutional affiliations. 